\title{
The economically important thrips from Malaysia, with a key to species (Thysanoptera, Thripinae)
}

\author{
Yong Foo $\mathrm{Ng}^{1}$, J Saiful Zaimi \\ I Centre for Insect Systematics (CIS), Universiti Kebangsaan Malaysia, 43600 Bangi, Selangor, Malaysia \\ 2 Malaysian Agricultural Research and Development Institute, MARDI Cameron Highlands 39007 Tanah \\ Rata, Pahang, Malaysia
}

Corresponding author: Yong Foo Ng (ng_yf@ukm.edu.my)

Academic editor: L. Mound | Received 18 July 2018 | Accepted 10 October 2018 | Published 20 December 2018

http://zoobank.org/F6CF8990-E9F2-4B6D-B3D7-D6D34498BEEC

Citation: Ng YF, Zaimi JS (2018) The economically important thrips from Malaysia, with a key to species (Thysanoptera, Thripinae). ZooKeys 810: 113-126. https://doi.org/10.3897/zookeys.810.28457

\begin{abstract}
An illustrated key is provided to the economically important Thripinae (Thysanoptera) of Malaysia, together with a checklist and information on hosts and distributions. Information about the diversity and pest status for these Thripinae is provided, together with the prominent character states that are useful for recognising each species.
\end{abstract}

\section{Keywords}

Economically important, Malaysia, Thripinae, thrips, Thysanoptera

\section{Introduction}

Of the 6200 thrips species worldwide (ThripsWiki 2018), most of the economically important pest species are members of the subfamily Thripinae. Notorious for their broad range of hosts, members of this subfamily are small, pale to dark brown in colour, and often occur in large populations. The common injuries are fruit scarring and flower decolouration, which directly lowers the aesthetic value and market price of crops. Moreover, crops infested by thrips may be banned from importation into countries with strict biological quarantine procedures, such as USA, Australia, Japan, and European countries. Other indirect damages include the reduction of crop yields due to foliage and flower dropping caused by the insect's feeding activities. Several species

Copyright YF Ng, J Saiful Zaimi. This is an open access article distributed under the terms of the Creative Commons Attribution License (CC BY 4.0), which permits unrestricted use, distribution, and reproduction in any medium, provided the original author and source are credited. 
of Thripinae are also the only known vectors of important plant tospoviruses (Moritz et al. 2003), such as the Tomato Spotted Wilt Virus (TSWV), Impatiens Necrotic Spot Virus (INSV), and other tospoviruses as reported by Rotenberg et al. (2015). Members of Thripinae can be identified only with certainty after careful mounting onto microscope slides. Partly due to a lack of trained workers and quick identification keys, the pest management practices for these minute insects in Malaysian agriculture and horticulture industry have been impeded, compared to temperate countries where thrips are generally better studied. For instance, although commonly occurring in a wide range of ornamental flowers and vegetable crops, there has been no identification key to the range of species found on crops in Malaysia. This paper introduces the economically important pest species of the subfamily Thripinae recorded from Malaysia, together with an illustrated key to these common pests. A list of host plants and distributions for each species are also included, and information on morphology and biology is also explained wherever possible. A key to the 65 genera of Thripinae recorded from South East Asia was provided by Mound and $\mathrm{Ng}$ (2009), and a key to the 23 species of the genus Thrips recorded from Peninsular Malaysia was provided by Mound and Azidah (2009).

\section{Material and methods}

The specimens studied were obtained by field sampling in Malaysia. Methods used for collecting were by hand-searching and beating. Samples collected were processed onto permanent microscopic slides in Canada Balsam, after maceration in $5 \% \mathrm{NaOH}$ and dehydration through a series of alcohols of $70 \%, 80 \%, 90 \%$ and absolute. These slides were then dried at $45{ }^{\circ} \mathrm{C}$ on a slide warmer, before being transferred into an oven for at least one month. All studied slides are deposited in the Centre for Insects Systematics (CISUKM), Universiti Kebangsaan Malaysia. Identifications and diagnoses were carried out with a differential interference contrast (DIC) microscope (Olympus BX41) as indicated in the photomicrographs that accompany the key provided here.

\section{Results}

\section{Key to the economically important thrips from malaysia}

1 Abdominal tergites with numerous rows of microtrichia (at least on the lateral third) (Fig. 10); antennae with 8 segments; body length usually about $1 \mathrm{~mm}$ or shorter.

- Abdominal tergites without numerous rows of microtrichia (Figs 8, 9); antennae with 7 or 8 segments (Fig. 7); body length usually more than $1 \mathrm{~mm}$......................2

2 Abdominal tergites VI-VIII with a pair of ctenidia laterally (Figs 8, 9) ...............3

- Abdominal tergites VI-VII without a pair of ctenidia laterally ...........................10

3 Ocellar setae pair I present (Figs 1, 4, 5); Pronotal anterior margin with 1 or 2 pairs

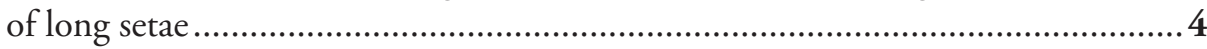


- Ocellar setae pair I absent (Figs 2, 3); Pronotal anterior margin without any pairs of long setae. 6

4 Tergite VIII of female without a posteromarginal comb of microtrichia; head with ocellar setae pair III close together and arising within ocellar triangle (Fig. 5) ......

Franklliniella schultzei

- Tergite VIII of female with posteromarginal comb of microtrichia; ocellar setae pair III arising just outside anterior margins of ocellar triangle (Fig. 4).........................5

5 Metanotum with a pair of campaniform sensilla (Fig. 17); postocular setae pair IV about as long as distance between hind ocelli Frankliniella occidentalis

- Metanotum without a pair of campaniform sensilla; postocular setae IV short, not longer than distance between hind ocelli (Fig. 4)

Frankliniella intonsa

6 Abdominal tergites with triangular lobes of craspedum on posterior margin (Fig. 8); prosternal basantra with several setae (Fig. 13)......Microcephalothrips abdominalis

- Abdominal tergites without craspedum (cf. Fig. 9); prosternal basantra never with setae ... 7

7 Ocellar setae II longer than setae III; postocular setae setae I and III usually long .

Stenchaetothrips biformis

- Ocellar setae II longer than setae III; postocular setae setae I and III usually short ...8

8 Metanotal median setae arising far the behind anterior margin (Fig. 16); abdominal sternites IV-VI without discal setae (Fig. 12) ........................ Thrips palmi

- Metanotal median setae arising at anterior margin (cf. Fig. 17); abdominal sternites IV-VI with discal setae (Fig. 11) ............................................................9

9 Postocular setae II stout, more than 0.5 as long as the distance between the bases of setae I and II (Fig. 2); forewing clavus apical setae usually as long as or longer than subapical (Fig. 19)

Thrips hawaiiensis

- Postocular setae II small, less than 0.5 as long as the distance between the bases of setae I and II (Fig. 3); forewing clavus apical setae usually shorter than subapical (Fig. 18)

Thrips florum

10 Ocellar setae I absent; abdominal tergite VIII posterior margin with microtrichial comb present medially (Fig. 24)

- Ocellar setae I present; abdominal tergite VIII posterior margin with or without microtrichial comb present medially (Fig. 24, 25) 12

11 Pronotum without prominent postero-angular setae (Fig. 21); metafurcal spinula weak or absent (Fig. 14)

Dichromothrips corbetti

- Pronotum with one pair of long postero-angular setae (Fig. 20); metafurcal spinula well developed (Fig. 15)

Dichromothrips smithi

12 Abdominal tergite VIII posterior margin with microtrichial comb present medially (cf Fig. 24) Ceratothripoides brunneus

- Abdominal tergite VIII posterior margin without microtrichial comb medially (Fig. 25)

13 Abdominal sternite VII posteromarginal setae arising in a row along posterior margin (Fig. 23); basal half antennal segments IV and V yellow (Fig. 6).

Megalurothips typicus

- Abdominal sternite VII posteromarginal median setae arise in front of posterior margin (Fig. 22); antennal segments IV and V entirely brown (Fig. 7) ...Megalurothips usitatus 

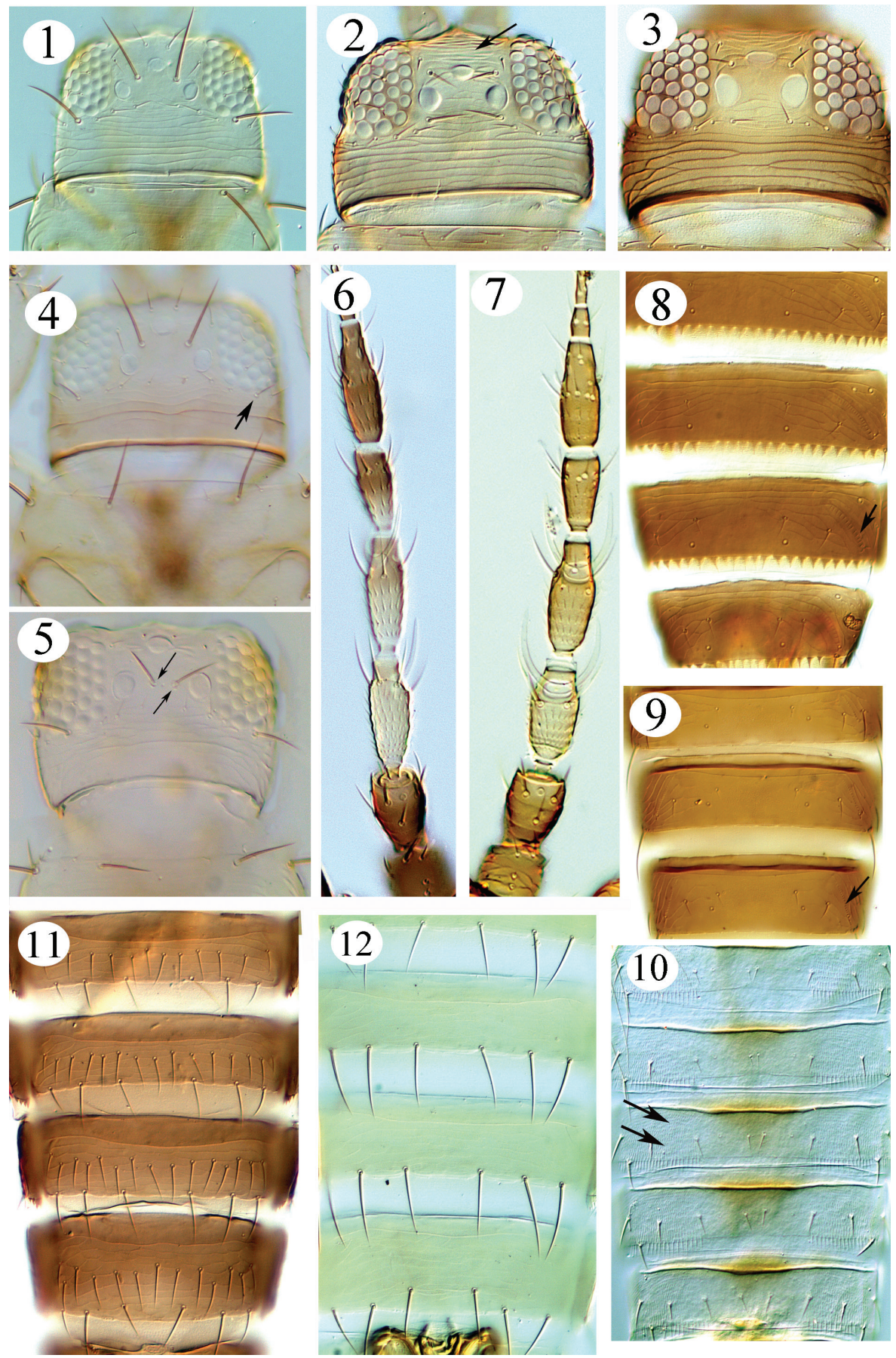

Figures I-I 2. Head: I Frankliniella occidentalis, 2 Thrips hawaiiensis, 3 Thrips florum, 4 Frankliniella intonsa, 5 Frankliniella schultzei. Antenna: $\mathbf{6}$ Megalurothips usitatus, 7 Megalurothrips typicus. Abdominal tergite: 8 Microcephalothrips abdominalis, 9 Thrips hawaiiensis, 10 Scirtothrips dorsalis. Abdominal sternite: II Thrips hawaiiensis, 12 Thrips palmi. 

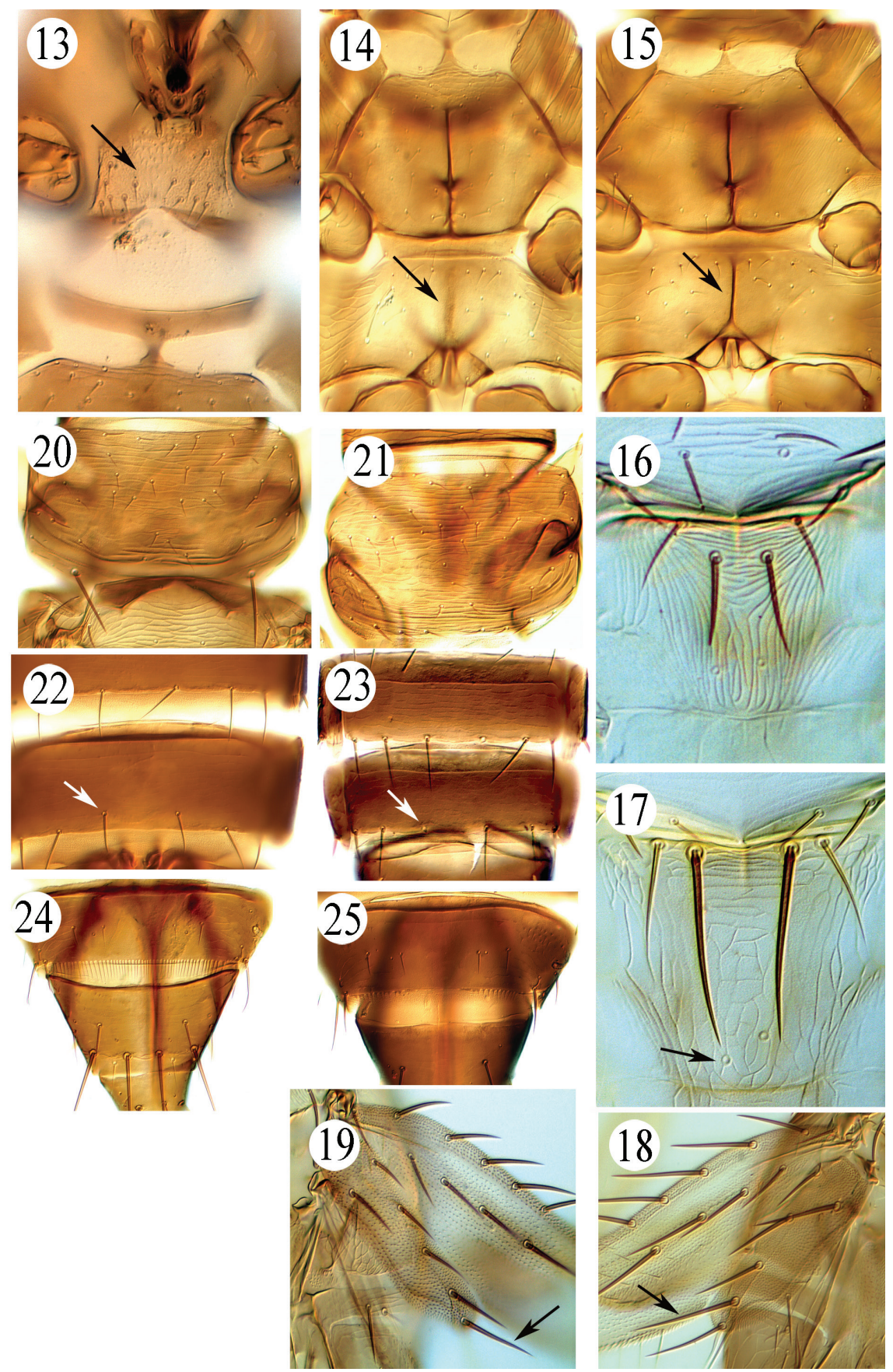

Figures 13-25. Prosternal basantra: 13 Microcephalothrips abdominalis. Meso- and Metasternum: 14 Dichromothrips corbetti, 15 Dichromothrips smithi. Metanotum: 16 Thrips palmi, 17 Frankliniella occidentalis. Forewing clavus: 18 Thrips florum, 19 Thrips hawaiiensis. Pronotum: 20 Dichromothrips smithi, 2I Dichromothrips corbetti. Abdominal sternite VII: 22 Megalurothips usitatus, 23 Megalurothips typicus. Abdominal tergite VIII: $\mathbf{2 4}$ Dichromothrips corbetti, $\mathbf{2 5}$ Megalurothips typicus. 


\section{Ceratothripoides brunneus Bagnall}

Five species are recognized in this genus, all from the Old World (Mound and Nickle 2009), but only $C$. brunneus has been found in Malaysia. A closely related species, $C$. claratris, has been reported as a pest (Murai 2000) and vector of tospoviruses on tomatoes in Thailand (Halaweh and Poehling 2009). This species was not detected in our collections, nor was it reported during earlier surveys (Mound and Azidah 2009). The species C. brunneus is from Africa, but has been found recently in Peninsular Malaysia on a range of different plant species (Table 1).

Recognition: Ceratothripoides brunneus is a large brown species; body largely brown except fore tibiae and antennal segment III paler brown, forewing uniformly brown; abdominal segment VIII posterior margin with complete comb of microtrichia; mesonotum and metanotum without pair of campaniform sensilla; male abdominal sternites III-VII with many small pore plates; male abdominal tergite IX without drepanae. This species is similar in structure to the species of Megalurothrips, Pezothrips, Odontothrips, and Odonthripiella, and these share many characteristics including a pair of dorso-apical setae on the first antennal segment. In this paper, this species and the legume-flower thrips (Megalurothrips) are distinguished based on the microtrichial comb on abdominal tergite VIII. Recognition of Ceratothripoides is easy if males are available, because the sternites have numerous pore plates (Mound and Nickle 2009).

\section{Dichromothrips corbetti (Priesner)}

Species of the genus Dichromothrips are usually found on orchids. In Peninsular Malaysia, only two species have been recorded so far, although three further species are recorded from western Malaysia - D. borneensis, $D$. nigricornis and $D$. major. The species $D$. corbetti originated from the Oriental Region but is now introduced worldwide via cultivated orchids. It was described from Vanda joaquim in Kuala Lumpur (Mound 1976), but is known from a wide range of Orchidaceae including Dendrobium spp., Arundina spp., Cattelya spp., and Vanda spp. from various localities in lowland Malaysia (Table 1).

Recognition: Large and dark brown species, forewing base paler, tarsi and tibial apex yellow; antennal segments brown, segment III and IV with apices elongate. Pronotum without long posteroangular setae, and metafurcal spinula diffuse or weakly defined. These characters are useful in distinguishing the species from the other members of the genus.

\section{Dichromothrips smithi (Zimmermann)}

The original material of this species is apparently lost (Mound 1976), and the species is recognized based on female specimens from Taiwan identified by H. Priesner. Recently, it has been reported as an invasive species in US on bamboo orchids (Arundina spp.) from Malaysia, Thailand and Taiwan (Department of Agriculture and Plant In- 
Table I. List of economically important thrips, their host plants and distribution in Malaysia.

\begin{tabular}{|c|c|c|c|c|}
\hline \multirow{2}{*}{ No. } & \multirow{2}{*}{ Thrips species } & \multicolumn{2}{|l|}{ Host plant } & \multirow{2}{*}{ Distribution } \\
\hline & & Family & Species & \\
\hline \multirow{5}{*}{1.} & \multirow{5}{*}{ Ceratothripoides brunneus } & Acanthaceae & Strobilanthes crispus & \multirow{5}{*}{ Pahang, Johor, Penang } \\
\hline & & Apocynaceae & Allamanda oenotheraefolia & \\
\hline & & Lamiaceae & Orthosiphon aristatus & \\
\hline & & Rubiaceae & Ixora sp. & \\
\hline & & Verbenaceae & Stachytarpheta mutabilis & \\
\hline \multirow{6}{*}{2.} & \multirow{6}{*}{ Dichromothrips corbetti } & \multirow{6}{*}{ Orchidaceae } & Aracnis sp. & \multirow{6}{*}{ Penang, Sarawak } \\
\hline & & & Arundina graminifolia & \\
\hline & & & Cattelya spp. & \\
\hline & & & Dendrobium spp. & \\
\hline & & & Phalaenopsis spp. & \\
\hline & & & Vanda spp. & \\
\hline 3. & Dichromothrips smithi & Orchidaceae & Arundina graminifolia & Pahang, Sarawak \\
\hline \multirow{13}{*}{4.} & \multirow{13}{*}{ Frankliniella intonsa* } & Alliaceae & Apapanthus campanulatus & \multirow{13}{*}{ Cameron Highlands, Pahang } \\
\hline & & Asteraceae & Dablia sp. & \\
\hline & & & Impatiens sp. var. wallerana & \\
\hline & & Balsamınaceae & Impatiens balsamina & \\
\hline & & Caryophyllaceae & Gypsophila sp. & \\
\hline & & Fabaceae & Vigna sinensis var. sesquipedalis & \\
\hline & & Iridaceae & Gladiolus sp. & \\
\hline & & Orchidaceae & Arundina graminifolia & \\
\hline & & Plantaginaceae & Antirrhiinum sp. & \\
\hline & & \multirow{2}{*}{ Rosaceae } & Fragraria ananassa & \\
\hline & & & Rosa sp. & \\
\hline & & Solanaceae & Solanum melongena & \\
\hline & & Verbenaceae & Verbena sp. & \\
\hline \multirow{9}{*}{5.} & \multirow{9}{*}{ Frankliniella occidentalis* } & Alliaceae & Agapanthus campanulatus & \multirow{9}{*}{ Penang, Cameron Highlands } \\
\hline & & \multirow{4}{*}{ Asteraceae } & Chrysanthemum morifolium & \\
\hline & & & Gerbera sp. & \\
\hline & & & Tagetes sp. & \\
\hline & & & Tanacetum parthenium & \\
\hline & & Iridaceae & Gladiolus sp. & \\
\hline & & Lamiaceae & Salvia farinacea & \\
\hline & & Plantaginaceae & Antirrhinum sp. & \\
\hline & & Rosaceae & Rosa sp. & \\
\hline \multirow{3}{*}{6.} & \multirow{3}{*}{ Frankliniella schultzei* } & Euphorbiaceae & Jatropha integerrima & \multirow{3}{*}{ Melaka } \\
\hline & & \begin{tabular}{|l|} 
Nyctaginaceae \\
\end{tabular} & Bougainvillea sp. & \\
\hline & & Plumbaginaceae & Plumbago auriculata & \\
\hline & & Fabaceae & Vigna sinensis & \\
\hline 7. & Megalurothrips usitatus & Fabaceae & Erythrina fusca & Perak, Penang, Pahang, Selangor \\
\hline & & Malpighiaceae & Tristellateia australasiae & \\
\hline & & Fabaceae & Canavalia rosea & \\
\hline 8. & Megalurothrips typicus & Moraceae & Artocarpus champeden & Perak, Penang \\
\hline & & Passifloraceae & Turnera ulmifolia & \\
\hline & & Acanthaceae & $\begin{array}{l}\text { Pseuderanthemum carruthersii var. } \\
\text { reticulatum }\end{array}$ & \\
\hline & Microcephalothrips & & Chrysanthemum indicum & \\
\hline 9. & abdominalis & & Cosmos sp. & Johor, Penang, Pahang \\
\hline & & Asteraceae & Cosmos caudatus & \\
\hline & & & Sphagneticola trilobata & \\
\hline
\end{tabular}




\begin{tabular}{|c|c|c|c|c|}
\hline \multirow{2}{*}{ No. } & \multirow{2}{*}{ Thrips species } & \multicolumn{2}{|l|}{ Host plant } & \multirow{2}{*}{ Distribution } \\
\hline & & Family & Species & \\
\hline & \multirow{5}{*}{$\begin{array}{l}\text { Microcephalothrips } \\
\text { abdominalis }\end{array}$} & \multirow{2}{*}{ Asteraceae } & Tagetes patula & \multirow{5}{*}{ Johor, Penang, Pahang } \\
\hline & & & Tridax procumbens & \\
\hline & & Heliconiaceae & Heliconia sp. & \\
\hline & & Orchidaceae & Oncidium sp. & \\
\hline & & Verbenaceae & Clerodendrum paniculatum & \\
\hline \multirow{9}{*}{10.} & \multirow{9}{*}{ Scirtothrips dorsalis* } & Anacardiaceae & Mangifera sp. & \multirow{9}{*}{$\begin{array}{l}\text { Penang, Perak, Kedah, } \\
\text { Terengganu, Melaka, Selangor }\end{array}$} \\
\hline & & Fabaceae & Caesalpinia pulcherrima & \\
\hline & & Fohocens & Cassia fistula & \\
\hline & & Fabaceae & Pithecellobium jiringa & \\
\hline & & \begin{tabular}{|l|} 
Fabaceae \\
\end{tabular} & Peliophorum pterocarpum & \\
\hline & & Myrtaceae & Psidium guajava & \\
\hline & & Rosaceae & Rosa alba & \\
\hline & & \multirow{2}{*}{ Solanaceae } & Capsicum annuum & \\
\hline & & & Solanum torvum & \\
\hline \multirow{16}{*}{11.} & \multirow{16}{*}{ Thrips hawaiiensis } & Anacardiaceae & Mangifera sp. & \multirow{16}{*}{$\begin{array}{l}\text { Selangor, Pahang, Terengganu, } \\
\text { Melaka }\end{array}$} \\
\hline & & Amaryllidaceae & Hymenocallis speciosa & \\
\hline & & Araceae & Zantedeschia aethiopica & \\
\hline & & A recoser & Areca catechu & \\
\hline & & Arecaceae & Dahlia sp. & \\
\hline & & Asteraceae & Aster dumosus & \\
\hline & & Euphorbiaceae & Jatropha integerrima & \\
\hline & & Leguminosae & Caesalpinia pulcherrima & \\
\hline & & Myrtaceae & Psidium guajava & \\
\hline & & Nyctaginaceae & Bougainvillea sp. & \\
\hline & & Orchidaceae & Arundina graminifolia & \\
\hline & & Plantaginaceae & Antirrhunum sp. & \\
\hline & & \multirow{3}{*}{ Rosaceae } & Fragraria ananassa & \\
\hline & & & Prunus perisica & \\
\hline & & & Rosa sp. & \\
\hline & & Verbenaceae & Clerodendrum paniculatum & \\
\hline \multirow{3}{*}{12.} & \multirow{3}{*}{ Thrips florum } & Apocynaceae & Plumeria rubra & \multirow{3}{*}{ Kedah, Penang } \\
\hline & & Verbenaceae & Clerodendrum paniculatum & \\
\hline & & & Lantana camara & \\
\hline \multirow{15}{*}{13.} & \multirow{15}{*}{ Thrips palmi* } & Anocinaceae & Allamanda oenotheraefolia & \multirow{15}{*}{ Selangor, Pahang, Melaka } \\
\hline & & Aросупасеае & Plumeria rubra & \\
\hline & & & Chrysanthenum sp. & \\
\hline & & & Cosmos sulphurous & \\
\hline & & Asteraceae & Sphagneticola trilobata & \\
\hline & & & Tagetes sp. & \\
\hline & & & Tagetes patula & \\
\hline & & Lamiaceae & Salvia farinaceae & \\
\hline & & Nyctaginaceae & Bougainvillea sp. & \\
\hline & & \multirow{4}{*}{ Orchidaceae } & Aracnis sp. & \\
\hline & & & Arundina graminifolia & \\
\hline & & & Dendrobium spp. & \\
\hline & & & Vanda spp. & \\
\hline & & Plumbaginaceae & Plumbago auriculata & \\
\hline & & Solanaceae & Solanum torvum & \\
\hline
\end{tabular}

*- Vector of Tospovirus (Mound 1996; Mound 2002; Rotenberg et al. 2015). 
dustry Division 2010), and as a pest of orchids in Korea (Lee et al. 2002). There are specimens in the CSIRO collection, Canberra, Australia labelled as being associated with damage to Vanilla plants in India. In Malaysia, this species has been taken only from Arundina graminifolia (Bamboo orchid) from Pahang and Sarawak with its distribution restricted to highlands.

Recognition: This large, dark brown species is similar in body colour to $D$. corbetti. It is distinguished by the fore wing with the subapical area paler, the pronotum with long posteroangular setae, and the metafurcal spinula well developed.

\section{Frankliniella intonsa Trybom}

This species is known as the European Flower Thrips, due to its wide distribution in Europe, but it causes less damage to horticulture than F. occidentalis. Both species share many morphological characteristics, but $F$. intonsa can be recognized by the shorter postocular setae, and the absence of paired campaniform sensilla on the metanotum. Both species also seem to share similar habitats, such that they have been recorded in Peninsular Malaysia only from highlands, but from a wide range of flowers in various plant families, including Plantaginaceae, Alliaceae, Verbenaceae, Orchidaceae, and Asteraceae.

Recognition: Body colour brown, tibiae and tarsi yellow; antennal segments III and IV yellow; forewing pale with dark setae. All species of Frankliniella have the forewing first and second veins with complete setal rows, the head with ocellar setae pair I present, and the pronotum with four pairs of long major setae. Tergite VIII posterior margin with comb of microtrichia in females but not in males.

\section{Frankliniella occidentalis (Pergande)}

This species is known as the Western Flower Thrips, and although originally from the South Western states of the USA it is now found worldwide (Moritz et al. 2001). Frankliniella is the largest genus in the family Thripidae, with 230 species mostly from Central and South America. F. occidentalis has been collected commonly in the Cameron Highlands on many different flower hosts, including roses, orchids, daisy, and chrysanthemum. However, two specimens were collected from Gerbera sp. at Penang Butterfly Farm. The species is an important vector of Tomato Spotted Wilt Virus (TSWV) and Impatiens Necrotic Spot Virus (INSV). However, there are very few or perhaps no records of these viruses being transmitted among Malaysian crops.

Recognition: Body length about $1.5 \mathrm{~mm}$ (female), male is smaller about $1.0 \mathrm{~mm}$ in length. Body colour varies from yellow to brown, abdomen sometimes shaded medially in specimens from Malaysia, forewing pale yellow, femora and tibiae yellow; antennal segments III, IV and V basal half pale, segments II and VI-VIII dark brown. Pronotum anterior margin with two pairs of long setae, metanotal campaniform sensilla present. Tergite VIII posterior margin with comb of microtrichia in females but not in males. 


\section{Frankliniella schultzei (Trybom)}

This species is widespread in tropical and sub-tropical countries. It is commonly collected in the lowlands of Peninsular Malaysia, breeding on flowers and leaves of many host plants. It has been sampled from flowers of Bougainvillea sp., Jatropha integerrima, and Plumbago auriculata. Frankliniella schultzei is an important vector of Tomato Spotted Wilt Virus (TSWV), although occasionally, it is a useful predator of mites on cotton (Milne and Walter 1997).

Recognition: This species apparently exists as two very different colour forms, with the body either brown or yellow. According Gikonyo et al. (2017) from the field surveys in Kenya indicate that the two colour forms of $F$. schultzei could be different species, of which, both showed distinct host preferences, lack of interbreeding and molecular differences. In general, F. schultzei is distinguished by the lack of ctenidia on abdominal tergite $\mathrm{V}$, the position of ocellar setae pair III between the posterior ocelli, and the absence from the posterior margin of tergite VIII of a comb of microtrichia.

\section{Megalurothrips usitatus Bagnall}

This is the most common and widespread species of the genus in the Oriental area. It breeds in legume flowers and is an important pest on bean crops through feeding in the flowers in south China (Tang et al. 2015).

Recognition: Body colour brown; fore tibiae, apices of mid and hind tibiae yellow; antennal segment III slightly yellow, segment IV and V brown; antennal segments III and IV with apical constriction, segment VI unusually elongate; abdominal sternite VII posteromarginal setae $S 1$ situated in front of posterior margin

\section{Megalurothips typicus Bagnall}

There are 13 species currently listed in Megalurothrips, but these are difficult to identify due to variation both within and between species. Correct identification of species in this genus requires morphological study and comparison of both sexes. In Peninsular Malaysia, only three species are reported: M. typicus, M. mucunae, and M. usitatus, and the latter species is the one most commonly collected on crops in both highlands and lowlands. Adults of M. typicus have been taken from Moraceae, Passifloraceae and Fabaceae, but with no reliable record of the host on which it breeds.

Recognition: This species is similar to $M$. sjostedti, the only species in this genus from Africa, but the colour of the forewing and antennae are different (Palmer 1987). Megalurothrips typicus is easy to distinguish from the other oriental Megalurothrips species, because all three pairs of posteromarginal setae on abdominal sternite VII arise at the posterior margin. 


\section{Microcephalothrips abdominalis (Crawford)}

This sunflower thrips is widespread worldwide, and is the only species in the genus $M i$ crocephalothrips. In Peninsular Malaysia, adults of this species have been collected largely from the plant family Asteraceae from Tagetes patula, Cosmos caudatus, Chrysanthemum indicum, Tridax procumbens, and Sphagneticola trilobata. Other plant families from which adults have been taken include Heliconiaceae, Orchidaceae, and Acanthaceae.

Recognition: Body largely brown except fore tibiae, tarsi, and antennal segment III slightly paler. Based on morphology, it is related to the Thrips genus-group, because of the presence of a pair of ctenidia on abdominal segments V-VIII, but no other member of this group has setae on the prosternum (Figure 13). The triangular lobed craspedum on the abdominal tergites is very distinctive character of this species. Pronotum without any long setae, surface smooth without any fine transverse lines. Forewing usually curved and vein setae small.

\section{Scirtothrips dorsalis Hood}

This species is widespread from Pakistan to Japan, Taiwan, and northern Australia (Hoddle and Mound 2003), and is now introduced to the Caribbean area and Florida. $S$. dorsalis is known as a vector of Tospovirus, the species often becomes a pest of many different crops including vegetables and cut-flowers in Southeast Asia. It was also found infesting young leaves of 'Berembang' tree (Sonneratia caseolaris) in UKM's green house. This mangrove tree is the host to firefly, Pteroptyx tener from Peninsular Malaysia.

Recognition: This is amongst the smallest of species in the subfamily Thripinae, with the body of both sexes usually less than $1 \mathrm{~mm}$. Body yellow, with all femora, tibiae, and tarsi yellow; antennal segment I pale, segment II variable pale or slightly shaded, segments III-VIII brown; forewings pale yellow to light brown, with apex paler. Abdominal tergites and sternites IV-VII with median brown marking. An identification key to the species of this genus is available in $\mathrm{Ng}$ et al. (2014).

\section{Stenchaetothrips biformis (Bagnall)}

This Oriental rice thrips breeds on grasses including paddy, on which crop it is a pest in Philippines and Thailand. However, such infestation has not been reported in Malaysia. This thrips usually lives in moist places like in paddy field and grasses by the pond site.

Recognition: Body uniformly brown; antennal segments I-II dark, II paler at apex, III pale, IV slightly shaded, V-VII dark; all tibiae and tarsi pale; fore wing uniformly shaded. Metanotum with closely spaced striations, campaniform sensilla absent, median setae arising behind the anterior margin but varying in position. Meso- and metafurca each without a spinula. Male abdominal sternites III-VII with a transverse pore plate. 


\section{Thrips florum Schmutz}

Identification of this species from its close relative, T. hawaiiensis, is not easy, and a third related species, T. razanii, was described recently from Peninsular Malaysia (Ng et al. 2010). For correct identification of these species it is essential that specimens are well-mounted onto slides. Thrips florum has not been reported as a severe pest in Malaysia's agriculture sector, but it has been collected from a wide range of flowers.

Recognition: Body colour brown; antennae brown except segment III yellow; legs yellow; forewing brown pale at base. Ocellar setae III arising outside ocellar triangle; postocular seta II much shorter than setae I and III. Mesonotum without sculpture lines near campaniform sensilla; metanotum with many lines at the anterior and laterally. Forewing clavus apical seta usually shorter than subapical seta. This species is very similar to both T. hawaiiensis and T. razanii, and comparisons are given in $\mathrm{Ng}$ et al. (2010). More discussion is available in Palmer (1999).

\section{Thrips hawaiiensis (Morgan)}

This is the most common and abundant species of the genus Thrips in Peninsular Malaysia, and is found on a wide range of cultivated plants in various families including Asteraceae, Apocynaceae, and Fabaceae. It is considered the pollinator of oil palm trees, but is reported as a pest of roses in Georgia, citrus in India, coffee and mangoes in Thailand, and banana in Australia (Palmer 1999).

Recognition: Body colour brown or bicoloured with head and pronotum paler than brown abdomen. Antennal segment III yellow, segments IV and V usually brown or paler at base; legs yellow; forewing paler at base. More discussion about the variation of this species is available in Palmer (1999) and $\mathrm{Ng}$ et al. (2010). A key to the species of Thrips genus from Peninsular Malaysia was published by Mound and Azidah (2009).

\section{Thrips palmi Karny}

This species is a common pest in Malaysia and also many other Southeast Asian countries. It is a vector of plant tospovisuses, but it can also cause severe feeding damage to the leaves of crops such as eggplant and capsicum (Tan et al. 2016).

Recognition: Body colour pale yellow; antennae 7-segmented, segments I and II pale yellow, other segments light brown. The species is easy to distinguish from most Thrips species because of the complete posteromarginal comb on abdominal tergite VIII and the lack of discal setae on abdominal sternites. In Malaysia, the species has been taken from crops including Capsicum, Cucumis and Solanum (Mound \& Azidah, 2009), as well as species of Rubiaceae. 


\section{Acknowledgements}

We would like to thank Dr. Laurence Mound for editing and suggestions that improved this manuscript. A special thank also to the reviewers for their invaluable comments. The study of Malaysian thrips (Thysanoptera) is funded by the Ministry of Science, Technology and Innovation (MOSTI) via research grant 06-01-02-SF0540 and Malaysia Toray Science Foundation via research grant STGL-002-2008.

\section{References}

Department of Agriculture and Plant Industry Division, The State of Hawaii (2010) Report to the Twenty-Fifth Legislature Regular Session of 2010: Report On the Fight Against Invasive Species for the Period of July 1, 2007 - June 30, 2008 \& July 1, 2008 - June 30, 2009.

Halaweh N, Poehling H-M (2009) Inheritance of vector competence by the thrips Ceratothripoides claratris (Shumsher) (Thysanoptera: Thripidae). Journal of Applied Entomology 133: 386-393. https://doi.org/10.1111/j.1439-0418.2008.01357.x

Hoddle MS, Mound LA (2003) The genus Scirtothrips in Australia (Insecta, Thysanoptera, Thripidae) Zootaxa 268:1-40. https://doi.org/10.11646/zootaxa.268.1.1

Gikonyo MW, Niassy S, Moritz GB, Khamis FM, Magiri E, Subramanian S (2017) Resolving the taxonomic status of Frankliniella schultzei (Thysanoptera: Thripidae) colour forms in Kenya - a morphological-, biological-, molecular- and ecological-based approach. International Journal of Tropical Insect Science 37(2): 57-70. https://doi.org/10.1017/ S1742758416000126

Lee GS, Ahn KS, Woo KS (2002) New record of Dichromothrips smithi (Zirmemann) (Thysanoptera: Thripidae) injurious to Orchidaceae in Korea. Journal Asia-Pacific Entomology 5(2): 155-160. https://doi.org/10.1016/S1226-8615(08)60146-6

Tang LD, Yan KL, Fu BL, Wu JH, Kui L, Lu YY (2015) The life table parameters of Megalurothrips usitatus (Thysanoptera: Thripidae) on four leguminous crops. The Florida Entomologist 98(2): 620-625. https://doi.org/10.1653/024.098.0235

Ministry of Agriculture and Agro-based Industry Malaysia (MOA) 2008: Annual Report: Ministry of Agriculture and Agro-based Industry Malaysia.

Milne M, Walter GH (1997) The significance of prey in the diet of the phytophagous thrips, Frankliniella schultzei. Ecological Entomology 22: 74-81. https://doi.org/10.1046/j.13652311.1997.00034.x

Moritz G, Kumm S, Mound LA (2003) Tospovirus transmission depends on thrips ontogeny. Virus Research 100: 143-149. https://doi.org/10.1016/j.virusres.2003.12.022

Mound LA, Ng YF (2009) An illustrated key to the genera of Thripinae (Thysanoptera) from South East Asia. Zootaxa 2265: 27-47.

Mound LA, David AN (2009) The Old-World genus Ceratothripoides (Thysanoptera: Thripidae) with a new genus for related New-World species. Zootaxa 2230: 57-63. 
Mound LA, Azidah AA (2009) Species of the genus Thrips (Thysanoptera) from Peninsular Malaysia, with a checklist of recorded Thripidae Zootaxa 2023: 55-68.

Mound LA (2002) So many thrips-so few tospoviruses? In: Marullo R, Mound LA (Eds) Thrips and Tospoviruses. Proceedings of the $7^{\text {th }}$. International Symposium on Thysanoptera. Australian National Insect Collection, Canberra, 15-18.

Mound LA (1996) The thysanoptera vector species of tospoviruses. Acta Horticulturae 431: 298-309. https://doi.org/10.17660/ActaHortic.1996.431.26

Mound LA (1976) Thysanoptera of the genus Dichromothrips on Old World Orchidacea. Biological Journal of the Linnean Society 8: 245-265. https://doi.org/10.1111/j.1095-8312.1976. tb00248.x

Murai T (2000) Damage to tomato by Ceratothripoides claratris (Shumsher) (Thysanoptera: Thripidae) in central Thailand and a note on its parasitoid, Goetheana shakespearei Girault (Hymenoptera: Eulophidae). Applied Entomology and Zoology 35:505-507. https://doi. org/10.1303/aez.2000.505

Ng YF, Eow LX, Mound LA (2010) A new species of genus Thrips (Thysanoptera, Thripinae) from flowers in Peninsular Malaysia. Zootaxa 2638: 65-68.

Ng YF, Mound LA, Azidah AA (2014) The genus Scirtothrips (Thysanoptera: Thripidae) in Malaysia, with four new Species and comments on Biltothrips, a related genus. Zootaxa 3856(2): 253-266. https://doi.org/10.11646/zootaxa.3856.2.6

Palmer JM (1987) Megalurothrips in the flowers of tropical legumes: a morphometric study. In: Holman J, Pelikan J, Dixon AFG, Weismann L (Eds) Population structure, genetics and taxonomy of aphids and Thysanoptera. SPB Academic Publishing, The Hague, 480-495.

Palmer JM (1992) Thrips from Pakistan to the Pacific: a review. Bulletin of the British Museum of Natural History (Entomology) 61: 1-76.

Rotenberg D, Jacobson AL, Schneweis DJ, Whitfield AE (2015) Thrips transmission of tospoviruses. Current Opinion in Virology 15: 80-89. https://doi.org/10.1016/j.coviro.2015.08.003

Tan JL, Ooi PAC, Khoo G (2016) Thrips on eggplant, chilli and bell pepper in Cameron Highlands, Malaysia. Serangga 21(1): 71-85.

ThripsWiki (2018) ThripsWiki - providing information on the World's thrips. Available from: http://thrips.info/wiki/Main_Page [Accessed 13.vii.2018] 